\title{
Pre and postoperative analgesia for orthopedic surgeries*
}

\section{Analgesia dos períodos pré e pós-operatório em cirurgias ortopédicas}

\author{
Verônica Ferreira de Aguiar Kawai', Paulo José Oliveira Cortez ${ }^{1}$, Vitor Engrácia Valenti², Fernando Rocha Oliveira ${ }^{2}$, Luciano \\ Magalhães Vitorino ${ }^{3}$
}

${ }^{*}$ Received from Teaching Hospital of Itajubá, School of Medicine of Itajubá, Itajubá, MG, Brazil.

DOI 10.5935/1806-0013.20150033

\section{ABSTRACT}

BACKGROUND AND OBJECTIVES: Pain is frequent in wards and impairs patients' treatment and recovery, especially orthopedic patients. So, this study aimed at evaluating pre and postoperative analgesic adequacy in patients submitted to orthopedic surgeries, and at looking for possible variables predicting the analgesic adequacy of such patients in both moments.

METHODS: This is a quasi-experimental study with two groups, orthopedic pre and postoperative periods, carried out through structured interview, physical evaluation and medical record analysis, in the Surgical Clinic of the Teaching Hospital, School of Medicine, Itajuba/MG, developed with patients in the pre and postoperative periods of orthopedic surgery.

RESULTS: Participated in the study 31 patients, all of them with medical prescription of some analgesic drug, being weak opioids those most frequently prescribed in $84 \%$ of preoperative cases, increasing to $87 \%$ in the postoperative period; $39 \%$ had no preoperative pain, decreasing to $36 \%$ in the postoperative period. On the other hand, $39 \%$ of patients had moderate to severe pain in the preoperative period, increasing to $45 \%$ in the postoperative period, being that $74 \%$ had analgesic adequacy in the preoperative period, increasing to $81 \%$ in the postoperative period.

CONCLUSION: Most patients of this study had adequate analgesia in the pre and postoperative periods of orthopedic surgery. In our sample, selected variables have not adequately predicted analgesic adequacy in both moments of the orthopedic surgery. Keywords: Analgesia, Orthopedics, Pain, Pain measurement.

1. Faculdade de Medicina de Itajuba, Hospital Escola de Itajuba, Departamento de Residencia Multiprofissional, Itajuba, MG, Brasil.

2. Universidade Estadual Paulista, Faculdade de Filosofia e Ciencias, Marilia, SP, Brasil.

3. Universidade Federal de Sao Paulo, Escola Paulista de Enfermagem, Sao Paulo, SP, Brasil.

Submitted in December 14, 2014

Accepted for publication in August 04, 2015.

Conflict of interests: none - Sponsoring sources: none.

Correspondence to:

Verônica Ferreira de Aguiar Kawai

Hospital Escola de Itajubá

Rua Miguel Viana, $\mathrm{n}^{\circ} 420$

37500-080 Itajubá, MG, Brasil.

E-mail: veronicky_eagle@yahoo.com.br

(C) Sociedade Brasileira para o Estudo da Dor

\section{RESUMO}

JUSTIFICATIVA E OBJETIVOS: A dor é comum nas enfermarias e dificulta o tratamento e a recuperaçáo dos pacientes, principalmente ortopédicos. Assim, o objetivo deste estudo foi avaliar a adequação da analgesia em pacientes submetidos a cirurgias ortopédicas, no pré e pós-operatório, e verificar possíveis variáveis preditoras da adequação analgésica desses pacientes nos dois momentos.

MÉTODOS: Trata-se de um estudo quase-experimental com dois grupos, pré e pós-operatório ortopédico, realizado através de entrevista estruturada, exame físico e análise de prontuário, na Clínica Cirúrgica do Hospital Escola da Faculdade de Medicina de Itajubá/MG, desenvolvido com pacientes no pré e pós-operatório de cirurgia ortopédica.

RESULTADOS: Foram avaliados 31 pacientes, todos tinham prescrição médica de algum fármaco analgésico, sendo o opioide fraco o mais prescrito em $84 \%$ dos casos no pré-operatório passando para $87 \%$ no pós-operatório; $39 \%$ não apresentavam dor no pré-operatório, diminuindo para $36 \%$ no pós-operatório. Por outro lado, $39 \%$ dos pacientes apresentaram dor moderada a intensa no pré-operatório, aumentando para $45 \%$ no período pós-operatório, $74 \%$ apresentaram adequação analgésica no pré-operatório, aumentando para $81 \%$ no pós-operatório.

CONCLUSÁO: A maiorparte dos pacientes desta pesquisa tinha adequação analgésica no pré e pós-operatório de cirurgia ortopédica. $\mathrm{Na}$ amostraestudada, as variáveis selecionadas não apresentaram predição da adequação analgésica nos dois momentos da cirurgia ortopédica.

Descritores: Analgesia, Dor, Mensuração da dor, Ortopedia.

\section{INTRODUCTION}

Pain is defined by the International Association for the Study of Pain (IASP) as an unpleasant sensory and emotional experience associated to real or potential tissue injury or described in terms of such injury ${ }^{1}$, which may be acute or chronic, able to leave sequelae and even to be life threatening $^{2}$. Calil \& Pimenta $^{3}$ have reported that after extensive literature review, it was found that pain in emergency situations, such as trauma, is poorly investigated and inadequately treated. In wards, orthopedists and nurses are daily faced with this symptom in the pre and postoperative periods of orthopedic surgeries. In the postoperative period, orthopedic patients have pain due to trauma-related tissue injury, 
functional physical activity of the surgery ${ }^{4}$, lack of pain evaluation and inadequate use of analgesics ${ }^{5,6}$. This pain makes difficult patients' management and recovery, since there are significant vital signs changes ${ }^{7}$.

A systematic review of factors influencing fast rehabilitation of patients submitted to total hip replacement has identified that patients with postoperative pain had higher incidence of hospital readmission and presentation to urgency sectors ${ }^{8}$. Evaluating, controlling and relieving pain has its humanitarian aspect and is also a vital part of trauma patients' management, because they contribute to the maintenance of physiological functions and accelerate the rehabilitation process $^{3}$. Pain is a stressor agent for patients, however actions for its better evaluation and management are poorly studied ${ }^{3}$. It should be evaluated and managed by a multiprofessional team ${ }^{9}$. Orthopedists and nurses play important role when deciding about evaluation, administration of additional analgesia and maintenance of pain ${ }^{6}$. When evaluating acute pain it is necessary to investigate location, intensity, onset, duration and periodicity of painful episodes, sensory quality, evolution pattern, worsening or improving factors and other associated symptoms ${ }^{3}$. Nurses, in their daily lives, evaluate and record patients' pain, however, in spite of the availability of strategies, they often do not adjust analgesia, ignoring prescribed drugs in an "as necessary" basis ${ }^{10}$.

A study by Silva, Pimenta $\&$ Cruz $^{10}$ has shown that ongoing education, both of the medical and the nursing team, had positive effect on pain evaluation and intensity recording, analgesic prescription and patients' recovery in the postoperative period. The visual analog scale (VAS) and verbal descriptors have been used to plan pain control therapy and to check the adequacy of suggested schedules ${ }^{3,11}$. VAS is a one-dimension scale of public domain ${ }^{12}$, provides an estimate of patients' pain, is easy to apply and has a score ${ }^{13}$. After search in Pubmed/Medline database, with Medical Subject Headings (MESH) "analgesia, pain measurement, orthopedic pain", and combination of Boolean operators "AND, OR and NOT", 282 studies with human beings in the last 10 years were found. The same strategy was used for the Scientific Electronic Library Online (Scielo) database, with Health Sciences Descriptors "analgesia, pain measurement, orthopedics, pain" however no published study has returned.

As from such considerations, this study aimed at evaluating analgesic adequacy in patients submitted to orthopedic surgeries in the pre and postoperative periods, and at observing potential predicting variables of analgesic adequacy for these patients in both moments.

\section{METHODS}

This was a prospective, quasi-experimental ${ }^{14,15}$, non randomized study with two groups, before and after orthopedic surgery, to collect information about patients' management. Participants were admitted to the Surgical Clinic of the Teaching Hospital of Itajubá, MG (HE-FMIt). Daily visits were carried out looking for patients under surgical treatment of fractures and who would meet inclusion criteria. Interviews and evaluations were carried out between January and August 2014. Tools were a structured questionnaire, physical evaluation and medical records analysis. Participated in the study 31 patients aged above 18 years, with Glasgow Coma Scale (GCS) score of $15^{16}$ and some type of bone fracture, being surgically treated by the orthopedic team.

Based on Calil \& Pimenta study ${ }^{3}$, a questionnaire was developed to characterize socio-demographic and clinical profile, in addition to describing pain intensity, use of analgesia and to evaluating the adequacy of analgesia for participants of the study. In the postoperative period, evaluation was carried out $24 \mathrm{~h}$ after surgery and no longer than $48 \mathrm{~h}$ later, because according to Landgraf et al. ${ }^{17}, 24 \mathrm{~h}$ after the procedure residual anesthesia effect has been already eliminated from the body. The following acute pain-related characteristics were evaluated: presence or absence of pain; location; intensity in VAS from 0 to 10, quality/type of pain; pain onset; pain duration; worsening and improving factors ${ }^{3}$. Pharmacological interventions were investigated on patients' medical records, as to schedule and administration. Analgesic prescriptions were classified as: exclusively analgesics; exclusively non-steroid anti-inflammatory drugs (NSAIDs); weak opioids and strong opioids ${ }^{3}$. Pain Management Index (PMI) was used to evaluate analgesic adequacy ${ }^{3}$. PMI aims at analyzing analgesic potency according to patient's referred pain intensity ${ }^{3}$. Analgesic potency (AP) was classified as: 0 - no analgesic drug; 1 - NSAIDs; 2 - weak opioid (codeine, tramadol); 3 - strong opioid (morphine, meperidine) ${ }^{3}$.

Software BioEstat version 5.0 and Minitab 16 were used for data analysis and calculation of descriptive statistics with mean, standard deviation, absolute and relative frequencies. Anderson Darling test has shown that samples had no normal distribution, so paired Student $t$ test was used to compare pain management before and after. Spearman correlation coefficient was also used with the classification: $0.00-0.19$ absent or very mild; $0.20-0.39$ mild; $0.40-0.59$ moderate; $0.60-0.79$ severe; and $0.80-1.00$ very severe ${ }^{18}$. Multivariate logistic regression was applied to identify possible predictors of pre and postoperative analgesia. Independent variables were age group, gender, education level, use of alcohol and illicit drugs, type of fracture, fracture segment, reason for the fracture, pain evaluation by physician, pain evaluation by nurse, use of analgesics and chronic disease. Outcome variable was analgesic adequacy in both periods. For all tests, $\mathrm{p}<0.05$ was considered significant.

The study was approved by the Research Ethics Committee, School of Medicine of Itajubá (FMIt), via Plataforma Brasil under opinion 496.465/2013.

\section{RESULTS}

After evaluating 31 patients, results are shown in table 1 . Results of socio-demographic characterization of patients (Table 1) have shown that $61 \%$ of patients were young/mature adults (18 to 49 years old); most (68\%) were males, $84 \%$ 
Table 1. Socio-demographic and clinic characterization of study participants

\begin{tabular}{|c|c|c|}
\hline & AF $(n=31)$ & $\mathrm{RF}(\%)$ \\
\hline \multicolumn{3}{|c|}{ Age group (years) } \\
\hline $18-29$ & 9 & 29 \\
\hline $30-49$ & 10 & 32 \\
\hline $50-59$ & 3 & 10 \\
\hline $60-79$ & 4 & 13 \\
\hline$>80$ & 5 & 16 \\
\hline \multicolumn{3}{|l|}{ Gender } \\
\hline Male & 21 & 68 \\
\hline Female & 10 & 32 \\
\hline \multicolumn{3}{|l|}{ Education } \\
\hline No education & 5 & 16 \\
\hline Up to 8 & 13 & 42 \\
\hline More than 8 & 13 & 42 \\
\hline \multicolumn{3}{|c|}{ Use of alcohol and illicit drugs } \\
\hline Yes & 13 & 42 \\
\hline No & 18 & 58 \\
\hline \multicolumn{3}{|l|}{ Type of fracture } \\
\hline Exposed & 4 & 13 \\
\hline Internal & 27 & 87 \\
\hline \multicolumn{3}{|l|}{ Fracture segment } \\
\hline Upper limbs & 13 & 42 \\
\hline Lower limbs & 18 & 58 \\
\hline Chest & 0 & 0 \\
\hline Spine & 0 & 0 \\
\hline Head & 0 & 0 \\
\hline \multicolumn{3}{|c|}{ Reason for fracture } \\
\hline Fall & 20 & 65 \\
\hline Car accident & 8 & 26 \\
\hline Others & 3 & 10 \\
\hline \multicolumn{3}{|c|}{ Use of analgesics at home } \\
\hline Yes & 25 & 81 \\
\hline No & 6 & 19 \\
\hline \multicolumn{3}{|l|}{ Chronic disease } \\
\hline Yes & 12 & 39 \\
\hline No & 19 & 61 \\
\hline
\end{tabular}

$\mathrm{AF}=$ absolute frequency, $\mathrm{RF}=$ relative frequency.

had some level of education, $58 \%$ have reported not using alcohol or illicit drugs. With regard to type of fracture, $87 \%$ had internal fracture, lower limbs were the most frequently affected with $58 \%$ of fractures and fall was the reason for most fractures $(65 \%)$.

Table 2 shows physicians and nurses who have evaluated pain in 52 and $29 \%$ of cases, respectively. Most patients (61\%) reported not having chronic disease and $81 \%$ used some analgesic at home when feeling pain.
Table 2. Evaluation of study participants' pain

\begin{tabular}{lll}
\hline Pain evaluation & AF $(n=31)$ & $R F(\%)$ \\
\hline By physician & & \\
Yes & 16 & 52 \\
No & 15 & 48 \\
By nurse & & \\
Yes & 9 & 29 \\
No & 22 & 71 \\
\hline $\mathrm{AF}=$ absolute frequency, RF = relative frequency. & &
\end{tabular}

Table 3 shows pain management index evaluation for study participants.

Table 3. Pain management index evaluation

\begin{tabular}{|c|c|c|c|c|}
\hline & \multicolumn{2}{|c|}{ Preoperative } & \multicolumn{2}{|c|}{ Postoperative } \\
\hline & $\underset{(n=31)}{\mathrm{AF}}$ & $\begin{array}{l}\mathrm{RF} \\
(\%)\end{array}$ & $\begin{array}{c}\mathrm{AF} \\
(\mathrm{n}=31)\end{array}$ & $\begin{array}{l}\text { RF } \\
(\%)\end{array}$ \\
\hline \multicolumn{5}{|l|}{ Analgesic potency (AP) } \\
\hline No drug & 0 & 0 & 0 & 0 \\
\hline Non-steroid anti-inflammatory & 5 & 16 & 1 & 3 \\
\hline Weak opioid & 26 & 84 & 27 & 87 \\
\hline Strong opioid & 0 & 0 & 3 & 10 \\
\hline \multicolumn{5}{|l|}{ Pain intensity $(\mathrm{Pl})$} \\
\hline No pain & 12 & 39 & 11 & 36 \\
\hline Mild pain & 7 & 22 & 6 & 19 \\
\hline Moderate pain & 4 & 13 & 8 & 26 \\
\hline Severe pain & 8 & 26 & 6 & 19 \\
\hline $\begin{array}{l}\text { Pain management index } \\
\text { (PMI=AP-PI) }\end{array}$ & & & & \\
\hline Adequate & 23 & 74 & 25 & 81 \\
\hline Inadequate & 8 & 26 & 6 & 19 \\
\hline
\end{tabular}

In analyzing analgesic potency (Table 3), it was identified that all patients had medical prescription for some analgesic. NSAIDs, such as intravenous (IV) dipirone $(500 \mathrm{mg}$ ) every 6h or IV ketoprofen $(100 \mathrm{mg}$ ) every $12 \mathrm{~h}$ were used in $16 \%$ of preoperative and just $3 \%$ of postoperative patients. Prescription of weak opioids in the pre and postoperative periods has predominated ( 84 and $87 \%$ ), such as IV tramadol $(50 \mathrm{mg})$ every $8 \mathrm{~h}$ or $100 \mathrm{mg}$ every $12 \mathrm{~h}$. It was identified in this teaching hospital that no patient has received preoperative prescription of strong opioids such as IV pethidine hydrochloride $(50 \mathrm{mg} / \mathrm{mL})+$ metoclopramide $(5 \mathrm{mg} / \mathrm{mL})+$ dipirone $(500 \mathrm{mg} / \mathrm{mL})$ every $6 \mathrm{~h}$. Absence of pain was higher in the preoperative period as compared to the postoperative period, however analgesic adequacy was better in the postoperative period.

There has been no statistically significant difference in pain management index in the pre and postoperative periods $(\mathrm{p}=0.207)$, as shown in table 4 .

Spearman correlation (Table 5) has shown that pain management index and classification of its management when carried 
Table 4. Pain management comparison in both periods

\begin{tabular}{lccc}
\hline Pain management & Preoperative & Postoperative & $\mathrm{p}<0.05$ \\
\hline Mean & 0.581 & 0.774 & $0.207 \mathrm{~ns}$ \\
Standard deviation & 1.311 & 1.117 & \\
\hline
\end{tabular}

t test: $p<0.05 . n s=$ non significant.

Table 5. Spearman Correlation between pain management index scores

\begin{tabular}{|c|c|c|}
\hline Pain evaluation & Preoperative & Postoperative \\
\hline & \multicolumn{2}{|c|}{ Mean pain management index } \\
\hline By physician & $r=-0.286 p=0.119$ & $r=-0.212 p=0.252$ \\
\hline \multirow[t]{2}{*}{ By nurse } & $r=0.068 p=0.718$ & $r=0.551 p=0.011^{*}$ \\
\hline & \multicolumn{2}{|c|}{ Pain management classification } \\
\hline \multicolumn{3}{|l|}{ By physician } \\
\hline $\begin{array}{l}\text { Adequate/Inade- } \\
\text { quate }\end{array}$ & $r=-0.019 p=0.919$ & $r=-0.16 p=0.933$ \\
\hline \multicolumn{3}{|l|}{ By nurse } \\
\hline $\begin{array}{l}\text { Adequate/Inade- } \\
\text { quate }\end{array}$ & $r=-0.52 p=0.780$ & $r=0.506 p=0.023^{*}$ \\
\hline
\end{tabular}

Significant correlation $p<0.05^{*}$

out by nurses had moderately significant correlation in the postoperative period.

Considering pain management as outcome variable in the multivariate logistic regression it was not possible to predict whether there is relationship between independent variables and pain management in the pre and postoperative periods of orthopedic surgeries $(\mathrm{p}=0.207)$.

\section{DISCUSSION}

The Committee of Sports Traumatology and the Brazilian Society of Orthopedics and Traumatology of Sáo Paulo have carried out a study in 2010 which has shown that perioperative pain management is seen as the most adequate practice because it potentiates the analgesic effect and decreases complications ${ }^{19}$.

Our study has shown that all patients were under some analgesic in the pre and postoperative periods. This practice is different from the study by Oliveira et al. ${ }^{20}$ which reports that most postoperative patients had not received analgesics, even with pain complaint ${ }^{21}$. Analgesic prescription in both situations is considered a positive factor, since it helps decreasing stress suffered by patients during admission, cooperates in decreasing infection risk, costs and incidence of readmissions $s^{7,8}$, decreases morbidity-mortality, in addition to promoting early activities, such as physiotherapy and ambulation ${ }^{22}$.

Analgesic prescription was more common with weak opioids, with $84 \%$ in the preoperative and $87 \%$ in the postoperative periods. This category of analgesics occupies the second step of the World Health Organization (WHO) analgesic ladder ${ }^{23}$. They are commonly used by orthopedists because they may or may not be associated to adjuvants ${ }^{21,23}$ to treat moderate pain, especially to control perioperative pain ${ }^{3}$.
Our study was carried out in a teaching hospital where medicine students and residents work every day, so it is valid to stress the importance of implementing ongoing education protocols and programs for pain management. This was well presented in a study by Moreira et al. ${ }^{24}$ which also shows lack of guidance with regard to the choice of adequate analgesic methods, deciding for the most popular prescription without taking into consideration whether this is the best indication for patients and may negatively influence, delaying their recovery and interfering with their quality of life.

In evaluating pain intensity before surgery, it is observed that $61 \%$ had some pain, and $64 \%$ had some pain after the procedure. The high incidence of pain in patients admitted for orthopedic treatment has to be stressed ${ }^{19}$. This is due to deficits in evaluation and interventions on postoperative pain. In many situations, the unprepared professional underestimates patient's complaint and real need. Barbosa et al. ${ }^{25}$ have carried out a study in a teaching hospital of the Triangulo Mineiro region and have identified similar results, where $65.6 \%$ of patients in the immediate postoperative period had some pain complaint. In our study, most nurses and almost half of physicians have not evaluated patients' pain, even with pain present in more than half of patients ${ }^{26}$.

It has been observed that $74 \%$ of orthopedic patients had adequate analgesia before surgery, going against the literature which shows analgesic inadequacy in the first evaluation. This number grows to $81 \%$ after procedure, in line with the study which shows better analgesic adequacy in the second evaluation ${ }^{3}$. Even with increased analgesic adequacy between pre and postoperative periods, this difference was not statistically significant.

We have identified PMI limitation in the studied sample. Even with adequate analgesia in both evaluated periods, there has been high level of moderate and severe pain in the preoperative (39\%) and postoperative (45\%) periods of orthopedic surgeries. Most pre and postoperative patients received weak opioids (84 and $87 \%$, respectively). Some studies mention the difficulty of orthopedists to prescribe strong opioids such as morphine ${ }^{27}$.

Our study has not identified the use of preoperative strong opioids such as morphine and only $10 \%$ of patients had this opioid prescribed for the postoperative period. Morphine is the first line opioid to treat moderate to severe pain and has advantages over other strong opioids ${ }^{28}$. Morphine in the first 24 postoperative hours of orthopedic procedures was associated to lower moderate to severe pain rates ${ }^{29}$. It is believed that high weak opioid prescription rates in both periods of this study may be associated to more complaints of moderate to severe pain among patients of this study.

Even with the low number of nurses $(29 \%)$ who have evaluated pain and recorded it on patients' medical records, Spearman correlation has identified that pain evaluation by nurses in the preoperative period has moderately and positively contributed for postoperative adequacy of analgesia. This finding was very important, because some studies show that postoperative pain still continues to be a major clinical problem ${ }^{30,31}$. Nurses are the primary responsible for care, comfort promotion and pain relief in the postoperative period ${ }^{32,33}$. 
Due to closer contact of nurses with patients, most physicians depend on nursing evaluations ${ }^{31}$. So, if nurses underestimate pain, it is possible that its management will be impaired ${ }^{32,33}$. Another important role of nurses in managing pain is analgesic administration, especially in the medical prescription modality "if necessary". In this modality, evaluation and drug administration require from nurses knowledge, professional responsibility and ethics ${ }^{32,34}$.

In our study, it was not possible to identify predictors of analgesic adequacy in the pre and postoperative periods by means of selected socio-demographic and clinical variables. Ribeiro et al. ${ }^{35}$ have used the pain management index to evaluate 41 patients in the postoperative period of appendectomies. They have not found significant association between clinical variables and analgesic adequacy. A study by Kamarul et al. ${ }^{36}$ has evaluated the use of analgesics to control pain of extremity and clavicle fractures in 42 adult patients to determine the association between the type of fracture (upper vs. lower limb) and pain management adequacy. Results have shown statistically significant association between age and pain intensity at arrival ( $\mathrm{p}=0.0015)$.

This study was limited by sample size ( 31 individuals), by the analysis of just the analgesic class (not relating administration route and dose) and by selection of type of anesthesia, which suggests that future studies should include these suggestions. Stressing that pain is subjective, it is worth reminding that the use of validated scales and tools is necessary for accurate evaluations.

\section{CONCLUSION}

Results have shown that most patients had analgesic adequacy in the pre and postoperative periods of orthopedic surgeries. However, many patients still had moderate to severe pain in both evaluated periods. With regard to selected variables, it was not possible to identify predictors of analgesic adequacy in both moments of orthopedic surgeries.

\section{REFERENCES}

1. International Association for Study of Pain (IASP). Consensus development conference statement: the integrated approach to the management of pain. J Accid Emerg Med. 1994;6(3):292-491.

2. Lima LR, Stival MM, Barbosa MA, Pereira LV. Controle da dor no pós-operatório de cirurgia cardíaca: uma breve revisão. Rev Eletr Enf. 2008;10(2):521-9.

3. Calil AM, Pimenta CA. [Pain intensity of pain and adequacy of analgesia]. Rev Lat Am Enfermagem. 2005;13(5):692-9. Portuguese.

4. Pasero C, McCaffery M. Orthopaedic postoperative pain management. J Perianesth Nurs. 2007;22(3):160-73.

5. White PF, Kehlet H. Improving postoperative pain management: what are the unresolved issues? Anesthesiology. 2010;112(1):220-5.

6. Roberts M, Brodribb W, Mitchell G. Reducing the pain: a systematic review of postdischarge analgesia following elective orthopedic surgery. Pain Med. 2012;13(5):71127.

7. Chester JG, Rudolph JL. Vital signs in older patients: age-related changes. J Am Med Dir Assoc. 2011;12(5):337-43.

8. Sharma V, Morgan PM, Cheng EY. Factors influencing early rehabilitation after THA: a systematic review. Clin Orthop Relat Res. 2009;467(7):1400-11.

9. Han X, Geffen S, Browning M, Kenardy J, Geffen G. Outcome evaluation of a mul- tidisciplinary pain management programme comparing group with individual change measures. Clin Psychologist. 2011;15(3):133-8.

10. Silva MA, Pimenta CA, Cruz Dde A. [Pain assessment and training: the impact on pain control after cardiac surgery]. Rev Esc Enferm USP. 2013;47(1):84-92. Portuguese.

11. Freitas CC, Vieira PR, Torres GV, Pereira CR. Avaliação da dor com o uso das escalas unidimensionais. Rev Dor. 2009;10(1):56-62.

12. Burckhardt CS, Jones KD. Adult measures of pain: The McGill Pain Questionnaire (MPQ), Rheumatoid Arthritis Pain Scale (RAPS), Short- Form McGill Pain Questionnaire (SF-MPQ), Verbal Descriptive Scale (VDS), Visual Analog Scale (VAS), and West Haven-Yale Multidisciplinary Pain Inventory (WHYMPI). Arthritis Rheum. 2003;49:S96-104

13. Hawker GA, Mian S, Kendzerska T, French M. Measures of adult pain: Visual Analog Scale for Pain (VAS Pain), Numeric Rating Scale for Pain (NRS Pain), McGill Pain Questionnaire (MPQ), Short-Form Mcgill Pain Questionnaire (SF-MPQ), Chronic Pain Grade Scale (CPGS), Short Form-36 Bodily Pain Scale (SF-36 BPS), and Measure of Intermittent and Constant Osteoarthritis Pain (ICOAP). Arthritis Care Res. 2011;63(Suppl 11):S240-52.

14. Grimshaw J, Campbell M, Eccles M, Steen N. Experimental and quasi-experimental designs for evaluating guideline implementation strategies. Fam Pract. 2000;17(Suppl 1):S11-6.

15. Sousa VD, Driessnack M, Mendes IA. An overview of research designs relevant no nursing: Part 1: quantitative research designs. Rev Lat Am Enfermagem. 2007;15(3):502-7.

16. Jennett B. Development of Glasgow Coma and Outcome Scales. Nepal J Neurosc. 2005;1(2):24-8.

17. Landgraf CS, Marques RC, Pires OC, Constantino E, Leite VR, Posso MB, et al. Avaliaçẫo da analgesia pós-operatória em um hospital universitário. Rev Dor. 2010;11(4):319-22.

18. Swinscow TD. Statistics at Square: ONE. 9th ed. [Internet].London: BMJ; 1997 [acesso em 21 fev 2015]. Disponível em: http://www.bmj.com/about-bmj/resources-readers/publications/statistics-square-one.

19. Silva RT, Marchetto A, Pedrinelli A, Santili C, Laurino CF, Meirelles ES, et al. Consenso brasileiro sobre dor perioperatória em ortopedia e traumatologia desportiva. Rev Bras Ortop. 2010;45(3):2-15.

20. Oliveira RM, Leitão IM, Silva LM, Almeida, PC, Oliveira SK, Pinheiro MB. Dor e analgesia pós-operatória: análise dos registros em prontuários Rev Dor. 2013;14(4):251-5.

21. Dadalt GT, Eizerik DP. Trauma físico: nível de dor relatado e analgésico prescrito. Rev Bras Farm. 2013;94(2):89-93.

22. Bassanezi BS, Oliveira Filho AG. Analgesia pós-operatória. Rev Col Bras Cir 2006;33(2):116-22.

23. Alivio del dolor en el cancer. Ginebr; OMS; 1987. 78p. pesquisa.bvsalud.org/portal/ resource/pt/rep-110876.

24. Moreira L, Truppel YM, Kozovitsvits FG, Santos VA, Atet V. Analgesia no pós-cirúrgico: panorama do controle da dor. Rev Dor. 2013;14(2):106-10.

25. Barbosa MH, Araújo NF, Silva JA, Corrêa TB, Moreira TM, Andrade EV. Avaliação da intensidade da dor e analgesia em pacientes no período pós-operatório de cirurgias ortopédicas. Esc Anna Nery. 2014;18(1):143-7.

26. Nascimento LA, Kreling MC. Avaliaçáo da dor como quinto sinal vital: opiniāo de profissionais de enfermagem. Acta Paul Enferm. 2011;24(1):50-4.

27. Webster BS, Verma SK, Gatchel RJ. Relationship between early opioid prescribing for acute occupational low back pain and disability duration, medical costs, subsequent surgery and late opioid use. Spine. 2007;32(19):2127-32.

28. Kraychete DC, Siqueira JT, Garcia JB e Grupo de Especialistas. Recommendations for the use of opioids in Brazil: Part II. Use in children and the elderly. Rev Dor. 2014;15(1):65-9.

29. Zaslansky R, Eisenberg E, Peskin B, Sprecher E, Reis DN, Zinman C, et al. Early administration of oral morphine to orthopedic patients after surgery. J Opioid Manag. 2006;2(2):88-92.

30. Bennett P, St Marie B. The epidemiology of pain. Core Curriculum for Pain Management Nursing. Philadelphia: WB Saunders Co; 2002. 45-53p.

31. Mac Lellan K. Postoperative pain: strategy for improving patient experiences. J Adv Nurs. 2004;46(2):179-85.

32. Bell L, Duffy A. Pain assessment and management in surgical nursing: a literature review. Br J Nurs. 2009;18(3):153-6.

33. Sloman R, Rosen G, Rom M, Shir Y. Nurses' assessment of pain in surgical patients. J Adv Nurs. 2005;52(2):125-32.

34. Duignan M, Dunn V. Congruence of pain assessment between nurses and emergency department patients: a replication. Int Emerg Nurs. 2008;16(1):23-8.

35. Ribeiro CO, Simone JC, Ramiro TH, Santos VS, Nunes MS, Alves JA. Dor em pacientes submetidos à apendicectomia. Rev Dor. 2014;15(3):198-201.

36. Kamarul AB, Abu Yazid MN, Mohd Idzwan Z, Rashidi A. A study on pain management for acute orthopaedic fracture in emergency department, hospital Universiti Sains Malaysia. Malaysian J Med Sci. 2006;13(1):179. 